13. Tkachenko, P. V. The synthesis of the substituted 4-alkyl/arylsulfonyl-5-amino-3-alkylthiopyrazoles as promising pharmaceutical agents with the antifungal action [Text] / P. V. Tkachenko, O. V. Tkachenko, K. Y. Netosova, O. V. Borisov, I. O. Zhuravel // Visnik Farmacii. - 2017. - Vol. 2, Issue 90. - P. 25-30. doi: 10.24959/nphj.17.2158

Рекомендовано до публікаиії д-р фарм. наук Колісник С. В. Дата надходження рукопису 03.10.2017

Pavlo Tkachenko, Postgraduate student, Department of Drug and Analytical Toxicology, National University of Pharmacy, Pushkinska str., 53, Kharkiv, Ukraine

61002, E-mail: toxchem@nuph.edu.ua

Olena Tkachenko, PhD, Associate Professor, Department of Quality Management, National University of Pharmacy, Pushkinska str., 53, Kharkiv, Ukraine, 61002

E-mail: elena_tkachenko75@ukr.net

Krystyna Netosova, PhD, Assistant, Department of Drug and Analytical Toxicology, National University of Pharmacy, Pushkinska str., 53, Kharkiv, Ukraine

61002, E-mail: kulikovskaja.k@gmail.com

Oleksandr Borisov, PhD, Head of Laboratory, LLC "RPE "Enamine”, Chervonotkatska str., 78, Kyiv, Ukraine, 02660 E-mail: boav.79@gmail.com

Iryna Zhuravel, Doctor of Chemical Sciences, Professor, Department of Clinical Biochemistry, Forensic Toxicology and Pharmacy, Kharkiv Medical Academy of Post-graduate Education, Amosova str., 58, Kharkiv, Ukraine, 61176

E-mail: irina.tox@gmail.com

\author{
UDC: 615.22:615.254:615.451.2:615.076:54.061/.062 \\ DOI: 10.15587/2519-4852.2017.113517
}

\title{
QUALITY ASSESSMENT AND STABILITY STUDY OF COMPOUNDED FUROSEMIDE SYRUP
}

\author{
(C) D. Alfred-Ugbenbo, O. A. Zdoryk, V. A. Georgiyants
}

Лікарські засоби виготовлені в аптеках для перорального застосування, приготовлені з використанням готових лікарських засобів у якості джерела активних фармачевтичних інгредієнтів, характеризуються короткими термінами придатності через їх нестабільність.

Метою даного дослідження є вивчення фізичної, хімічної та мікробіологічної стабільності сиропів фуросеміду аптечного виготовлення впродовж 30 днів.

Матеріали і методи: Серії сиропів аптечного виготовлення 5 мг/мл, виготовлених з субстанції фуросеміду і таблеток (двох виробників) в якості джерел активних фармацевтичних інгредієнтів, зберігали в темному місиі при температурі $5 \pm 3{ }^{\circ} \mathrm{C}$ та $23 \pm 2{ }^{\circ} \mathrm{C}$ для яких досліджували на 0, 7, 15, 23 та 30 дні зміни фізичної (рН, колір, запах, виділення газу, в'язкість), хімічної та мікробної стабільності. Було проведено стрес-тест, щэоб відрізнити ознаки хімічної нестабільності, використовуючи метод тонкошарової хроматографії. Досліджувані зразки протягом терміну зберігання досліджували на мікробіологічну стабільність визначаючи загальну кількість аеробних мікробів (ТАМС <100), загальну кількість комбінованих дріжджів/ивілевих грибів (ТYМС <10) та відсутність Escherichia coli.

Результати: Протягом усього терміну зберігання для досліджуваних сиропів було не виявлено додаткових плям на хроматограмі, суттєвих змін рН, кольору, запаху, утворення газу, в'язкості. На 30-й день у досліджуваних зразках вміст фуросеміду складав ( $\geq 99,3$ \%), загальний обсяг аеробних мікроорганізмів $\left(<10^{2}\right)$, загальний сумарний вміст дріжджів/цвілевих грибів $\left(<10^{1}\right)$, шео є у межах допустимих значень. Зразки для яких перевіряли вплив стрес факторів на ТШХ хроматограмі виявили наявність додаткових плям та зміни їх інтенсивності.

Висновки: Досліджено, щуо екстемпоральні сиропи фуросеміду, виготовлені як із субстаниії так $і$ таблеток, які зберігаються в скляних флаконах у темному місиі при $5 \pm 3{ }^{\circ} \mathrm{C}$ та $23 \pm 2{ }^{\circ} \mathrm{C}$, фізично, хімічно та мікробіологічно стабільні принаймні протягом 30 днів.

Ключові слова: фуросемід, сироп, лікарські засоби виготовлені в аптеках, внутрішньоаптечний контроль якості, стабільність, тонкошарова хроматографія.

\section{Introduction}

The need for compounded preparations as a panacea for patient-specific dosing, logistical and therapeuti- cal quagmires in pharmacotherapy is usually faced with the challenge of affirming their stability. Dispersed solid dosage forms are often used as active pharmaceutical 
ingredients (API) in compounding oral dosage forms for patients whose prescriptions contain doses different from available standard manufactured formulations $[1,2]$.

\section{Formulation of the problem in a general} way, the relevance of the theme and its connection with important scientific and practical issues

Excipients from finished products in extemporal oral liquids alter the environment and properties of the dispersion medium ( $\mathrm{pH}$, viscosity, etc) and this may lead to microbiological, chemical or physical instability. These in turn are reflected in formation of unwanted products, degradation and change in potency or strength of API. Due to these factors, certain limits on beyond-use-dates (BUDs) were introduced to manage potential risks from extemporaneous preparations with unknown stability data.

\section{Analysis of recent studies and publications in} which a solution of the problem are described and to which the author refers

The United States Pharmacopoeia(USP), in the absence of data about microbial purity, recommends a conservative storage period of 48 hours for low-risk and 24 hours for high-risk oral liquid preparations at 20 $25^{\circ} \mathrm{C}[3-5]$. For compounded nonsterile preparations, a fourteen days storage period at controlled cold temperature is recommended [6]. Commercially available relatively pH-stable vehicles such as Ora-plus, Syr-spend, etc for which prescribed APIs can be dispersed and dispensed have been in use in predominantly western countries. Most stability tests are conducted using these vehicles as the dispersion medium [7-10]. However, these vehicles are neither used in Ukraine nor in Nigeria.

4. The field of research considering the general problem, which is described in the article

Syrup USP is a cheap, viscous [11] and readily available vehicle for dispersing such APIs even for resource-limited countries. Sequel to our suggestion on the need to conduct stability studies not just for pharmacy compounded medicines but on more affordable alternative dispersion media [12].

\section{Formulation of goals (tasks) of article}

This work is aimed at investigating the stability of furosemide in simple syrup made from both substance and dispersed commercial brands.

6. Presentation of the main research material (methods and objects) with the justification of the results

\begin{tabular}{cc}
\multicolumn{2}{c}{ Composition of syrups: } \\
Composition 1 & Composition 2 \\
Comp & Furosemide ex tab $0.5 \mathrm{~g}$ \\
Furosemide $0.5 \mathrm{~g}$ & Syrup USP $\quad 100 \mathrm{ml}$ \\
Syrup USP $100 \mathrm{ml}$ &
\end{tabular}

Materials. Furosemide (FRU) substance from Ipca Laboratories Ltd. India (batch 5074HRII), furosemide tablets $40 \mathrm{mg}$ («Arterium», batch 118840, Ukraine), furosemide tablets $40 \mathrm{mg}$ («Sanofi», batch 114402, Ukraine) and Sucrose (pharmaceutical grade). Simple syrup USP $(85 \% \mathrm{w} / \mathrm{v})$ was compounded according to instructions for its preparation [13].
Chemicals. All reagents and solvents meet and were prepared in accordance with the requirements of The State Pharmacopoeia of Ukraine (SPhU) which agreed with European Pharmacopoeia [14].

Equipment. Class A Volumetric glassware, filter paper (FILTRAK® Acido Hydrochlorico Extraca), UVspectrophotometer (Thermoscientific Evolution 60S, USA) with $10 \mathrm{~mm}$ quartz cells, mortar, pestle, analytical balance (AXIS, Poland ALN220), microsyringe (SGE Analytical Science Batch 003000, Australia), TLC Silicagel $254 \mathrm{~nm}$ chromatographic (SUPELCO lot BCBR8417V, Germany), $\mathrm{pH}$ meter (pH-150MI, Russia), capillary glass viscometer («VLG-2», Russia), 400 watts UV-lamp («Lensovnarhoz», Russia), biological safety cabinet AS2-4E1 (Esco, Indonesia).

Compounding technology: Pulverize $500 \mathrm{mg}$ of substance (or tablet equivalent) of furosemide with a small portion of syrup to form a paste. Add syrup gradually with stirring to form a homogenous mixture. Fill the mixture with the same base up to $100 \mathrm{ml}$ to form $5 \mathrm{mg} / \mathrm{ml}$ syrup.

Forced degradation study. $20 \mathrm{mg}$ of furosemide pure substance samples were subjected to stress conditions by adding $1 \mathrm{ml}$ each of $3 \%$ hydrogen peroxide, $0.1 \mathrm{M}$ sulfuric acid, $0.1 \mathrm{M}$ hydrochloric acid, $0.1 \mathrm{M}$ sodium hydroxide and placed in a water bath at $78 \pm 2{ }^{\circ} \mathrm{C}$ for one hour. A separate sample containing the same substance was held under UV light for fourteen hours. All samples were analyzed 24 hours later from the onset of their subjection to stress conditions. Portions of the stressed samples are examined using identification and assay tests described below in the "chemical stability section".

Stability. For stability assessment, $5 \mathrm{mg} / \mathrm{ml}$ of furosemide substance (FRUst) and dispersed tablets of two market brands (“Arterium» - $\mathrm{T}_{1}$, «Sanofi» $-\mathrm{T}_{2}$ ) with syrup USP were stored in the dark at $5 \pm 3{ }^{\circ} \mathrm{C}$ and $23 \pm 2{ }^{\circ} \mathrm{C}$ for 30 days. Each of these batches were analyzed immediately (day 0) and at days 7, 15, 23, 30 using the methods described below.

\section{Chemical stability}

Identification by thin layer chromatography (TLC):

Test solutions: $20 \mathrm{mg}$ furosemide equivalent with samples were dissolved in $30 \mathrm{ml}$ methanol and sonicated for 5 minutes. After making up to $50.0 \mathrm{ml}$ with the same solvent, they were filtered.

Reference solution: $20 \mathrm{mg}$ of furosemide pharmaceutical substance was dissolved in $30 \mathrm{ml}$ methanol and sonicated for 5 minutes. It was then filled to $50.0 \mathrm{ml}$ with the same solvent.

A twin trough chamber was saturated with a chloroform-ethylacetate-glacial acetic acid (7:3:0.5 v/v ml) mobile phase and filter paper for $20-30$ minutes. $1 \mu \mathrm{L}$ of each sample was applied to the TLC plate with the use of a microsyringe.

The system was developed vertically over a distance of $8 \mathrm{~cm}$ and dried in air. Detection was made with the aid of an $\mathrm{UV}_{254 \mathrm{~nm}}$ lamp.

Stored samples were examined at the end of each designated storage period and observed for formation of new spots other than that of furosemide, retardation factor (Rf) of corresponding spots beyond $\Delta 0.02$ of reference substance, disappearance/diminishing of spots. 
Assay: $20 \mathrm{mg}$ furosemide equivalent with syrup samples was dissolved in $30 \mathrm{ml}$ of $0.1 \mathrm{M}$ sodium hydroxide $R$ and allowed to stand for 20 minutes. The mixture was then diluted with the same solvent to $50.0 \mathrm{ml}$ and filtered. After discarding the first $10 \mathrm{ml}$ of the filtrate, an aliquot of $2.5 \mathrm{ml}$ was diluted to $100.0 \mathrm{ml}$ with $0.1 \mathrm{M}$ sodium hydroxide $R$. The absorbance of the analytical solution was measured by a UV spectrometer at $271 \mathrm{~nm}$ using $0.1 \mathrm{M}$ sodium hydroxide as the compensation solution. The content of $\mathrm{C}_{12} \mathrm{H}_{11} \mathrm{C}_{1} \mathrm{~N}_{2} \mathrm{O}_{5} \mathrm{~S}$ was calculated by method of specific absorbance taking 580 as the value of A $(1 \%, 1 \mathrm{~cm})$ at $271 \mathrm{~nm}[15]$ :

Stored samples were assayed at the end of each designated storage period and observed for degradation beyond the USP accepted limits of $\pm 10 \%$ for content of active ingredient over the storage period.

Physical stability. Parameters such as $\mathrm{pH}$, viscosity, and organoleptics were measured. At each point, the measuring instruments were calibrated at regular intervals as recommended by the manufacturers. The $\mathrm{pH}$ was measured using a digital $\mathrm{pH}$-meter at the same temperature $\left(20-25^{\circ} \mathrm{C}\right)$.

The kinematic viscosity of the samples was measured using a capillary viscometer at a temperature of $20 \pm 0.5^{\circ} \mathrm{C}$ according to the requirements of the general chapter «2.2.9. Capillary viscometer method» [16]. The viscometer through tube was filled with a sufficient quantity of the syrup to be examined. The viscometer was immersed in the bath of water at $20 \pm 0.1{ }^{\circ} \mathrm{C}$, and allowed to stand for $30 \mathrm{~min}$. The time required for the level of the liquid to drop through the specified mark was measured with a stop-watch. The kinematic viscosity was calculated using the formula:

$$
\mathrm{V}\left(\mathrm{mm}^{2} / \mathrm{s}\right)=\mathrm{t} \times \mathrm{k},
$$

where $t$ - flow time, in seconds, of the liquid to be examined, $k$-constant of the viscometer, expressed in square millimetres per square second $\left(2.894 \mathrm{~mm}^{2} / \mathrm{s}^{2}\right)$.

Organoleptic tests were provided for changes in physical appearance, odour, formation of gas and taste. Examination of the samples was carried out according to the general chapter of the European pharmacopoeia «2.2.1. Clarity and degree of opalescence of liquids». Identical test tubes of colourless, transparent, neutral glass with a flat base and an internal diameter of 15-25 mm were used to compare the liquid to be examined with a reference suspension freshly prepared, the depth of the layer being $40 \mathrm{~mm}$. The syrups were compared in diffused daylight 5 min after preparation of the reference suspension, viewing vertically against a black background.

Microbiological stability. Stored samples were investigated according to the pharmacopoeia method «2.6.12. Microbiological examination of non-sterile products: total viable aerobic count» [16]. The following medium was used: casein soya bean digest agar (for the determination of the total amount of viable aerobic microorganisms (TAMS), Sabouraud-dextrose agar (for determining the total combined yeasts/mould count (TYMC), soybean casein broth (for preliminary incubation in determining the presence of certain types of microorganisms), MacConkey agar (for identification of Escherichia coli). The following strains of microorgan- isms from the American Type Culture Collection (ATCC) were used to estimate the activity of the tested compounds Staphylococcus aureus ATCC 6538, Pseudomonas aeruginosa ATCC 9027, Bacillus subtilis ATCC 6633, Candida albicans ATCC 10231, Aspergillus brasiliensis ATCC 16404.

15-20 $\mathrm{ml}$ of casein soya bean digest agar or Sabouraud-dextrose agar were placed in sterile Petri dishes at a temperature of $45-50{ }^{\circ} \mathrm{C}$, and the agar was allowed to cool. $1 \mathrm{ml}$ of the prepared test-sample (dilution $1: 10)$ was introduced into sterile tubes containing $4 \mathrm{ml}$ of the corresponding molten and cooled agar. The contents of the test tube were quickly stirred, transferred to prepared Petri dishes and evenly distributed throughout the upper layer of the medium. After cooling the agar, the cups were incubated at a temperature of $30-35^{\circ} \mathrm{C}$ for 5 days (for bacteria), at a temperature of 20-25 ${ }^{\circ} \mathrm{C}$ for 7 days (fungi).

Culture media of these samples were examined for microbial stability based on the total aerobic microbial count (TAMC $<100$ ), the total combined yeasts/moulds count (TYMC<10) and absence of Escherichia coli.

Sedimentation volume. After a 30 day storage period, the stored samples were shaken and transferred to a $100 \mathrm{ml}$ graduated measuring cylinder. The sedimentation values $[17,18]$ were measured immediately and after 10 minutes of standing with a help of the stop watch. The sedimentation volume, $\mathrm{F}$, defined as the ratio of the equilibrium (or final) volume of sediment $\mathrm{V}_{\mathrm{u}}$ to the total volume of the suspension $\mathrm{V}_{\mathrm{o}}$, was measured and calculated using the formula:

$$
\mathrm{F}=\mathrm{V}_{\mathrm{u}} / \mathrm{V}_{\mathrm{o}} \text {, }
$$

where $\mathrm{F}$, ranges between 0 and 1 . The preparation was considered stable if $\mathrm{F} \geq 0.9$.

Content uniformity: Ten well-mixed units (per $10 \mathrm{ml}$ ) of the $5 \mathrm{mg} / \mathrm{ml}$ syrup (composition 2) stored in the dark for 30 days at $23 \pm 2{ }^{\circ} \mathrm{C}$ were measured and the uniformity of dose was analyzed according to the European Pharmacopoeia's «2.9.40 Uniformity of Dosage Units». Ten portions (per $10 \mathrm{ml}$ ) of well-prepared $5 \mathrm{mg} / \mathrm{ml}$ syrup were taken for assay using the UV spectroscopic specific absorbance method. Each portion was dissolved in $100 \mathrm{ml}$ volumetric flask, $10 \mathrm{ml}$ of $0.1 \mathrm{M}$ sodium hydroxide was added. The mixture was shaken and allowed to stand for 20 minutes, and then diluted with the same solvent to $100 \mathrm{ml}$. $2 \mathrm{ml}$ of the obtained solution were diluted to $100 \mathrm{ml}$ with $0.1 \mathrm{M}$ sodium hydroxide. The absorbance was measured at $271 \mathrm{~nm}$ using $0.1 \mathrm{M}$ sodium hydroxide as the compensation solution. Calculation was carried out as described in the assay method above.

\section{Results and discussion}

Forced degradation study. As a template for studying a change in our syrup over time, samples of furosemide were stressed and assessed by a suitable TLC method and a UV-spectrophotometric assay method. Results, as seen in Fig. 1, show that all samples had spots aligning with that of the reference sample. However, the FRU spots for $\mathrm{H}_{2} \mathrm{O}_{2}, \mathrm{HCl}$ and $\mathrm{H}_{2} \mathrm{SO}_{4}$ had varying degrees of diminished spots, thereby agreeing with results from assay (Fig. 2) about degradation in these samples. 


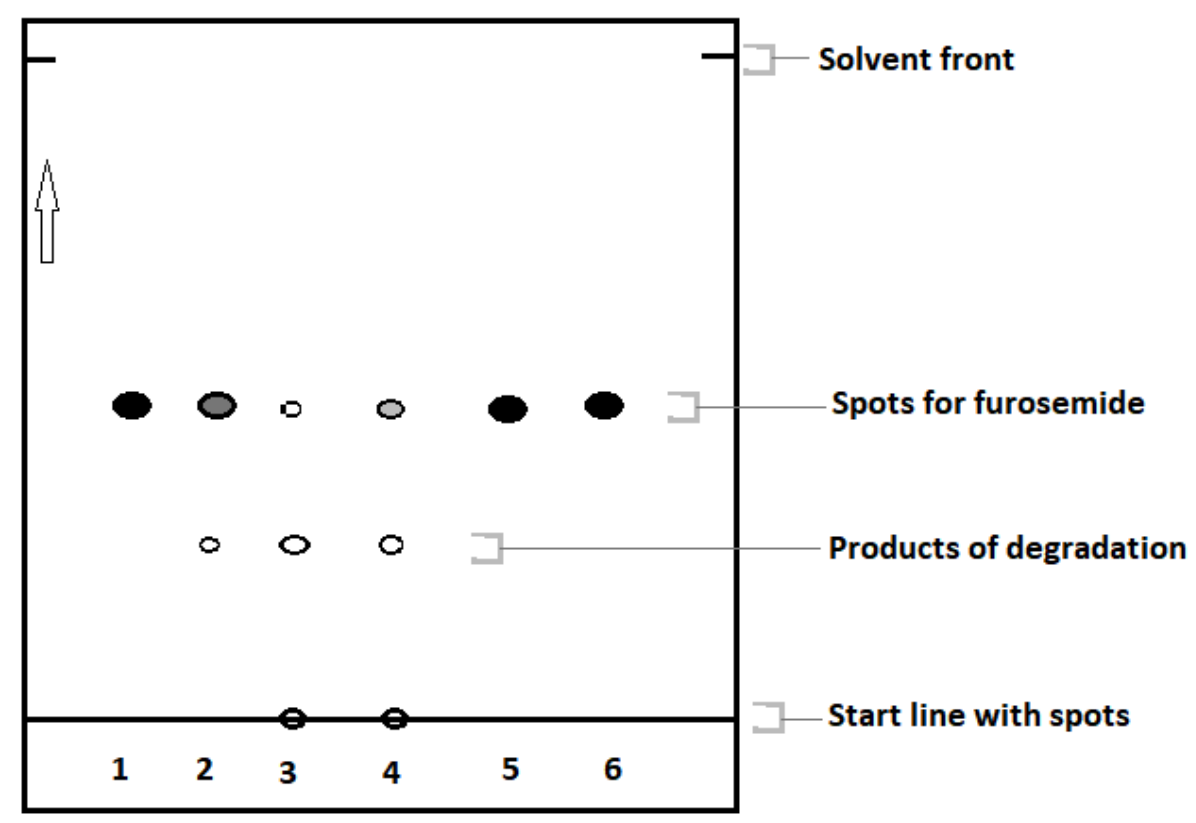

Fig 1. Schematic representation of chromatograph showing products of furosemide degradation as seen under the UV light. Spots with faint or no colour represent samples that underwent degradation under stress conditions. Key: 1 - reference solution, 2 - sample with $\mathrm{H}_{2} \mathrm{O}_{2}, 3$ - sample with $\mathrm{H}_{2} \mathrm{SO}_{4}, 4$ - sample with $\mathrm{HCl}, 5$ - sample with $0.1 \mathrm{NaOH}$, 6 - sample stressed by UV light

Products of degradation in these three samples were revealed on the chromatograph at $\mathrm{R}_{\mathrm{f}^{-}} 0.21(0.23$ for $\mathrm{H}_{2} \mathrm{O}_{2}$ ). No significant change for samples stressed by $0.1 \mathrm{M} \mathrm{NaOH}$ indicate that furosemide is not only stable to thermal degradation $\left(\mathrm{T} \leq 78{ }^{\circ} \mathrm{C}\right)$ but also, relatively stable in alkaline medium, hence, its (sodium hydroxide) recommended as a suitable solvent for assay.
Although no significant change was seen on the chromatogram, the assayed value $(107 \%)$ for the UV stressed sample (Fig. 2) prompts the advice to put it in amber bottles as storage containers or store away from light.

Chemical stability. Results in table 1 tell us that no extra spots were seen after routine examination of samples during the 30 days of storage.

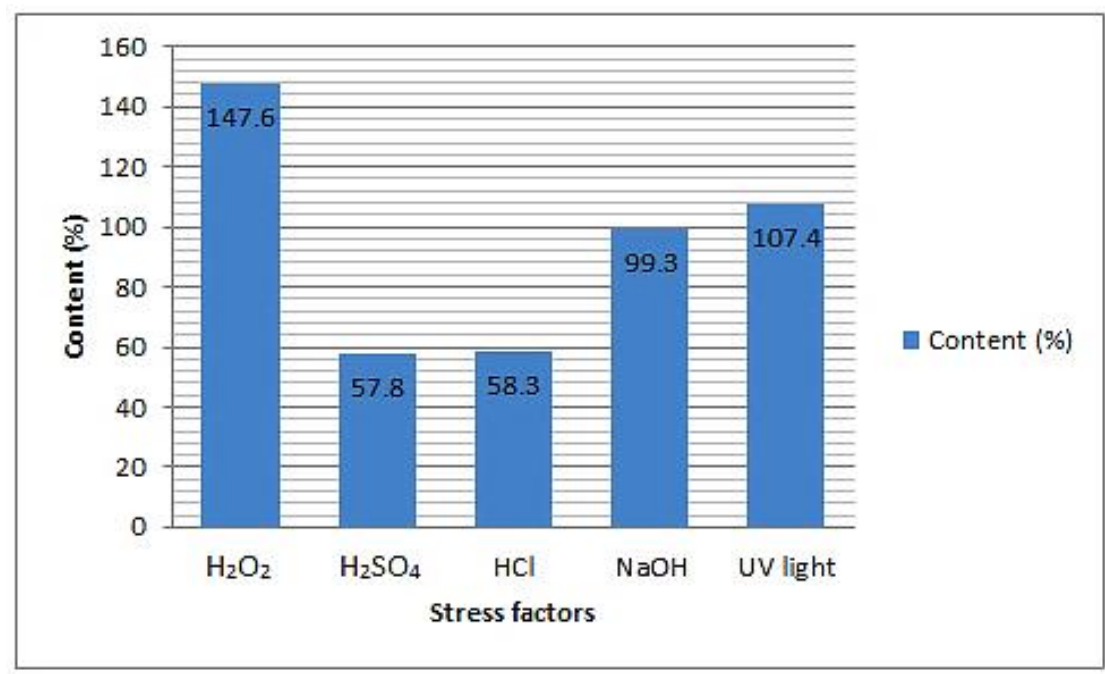

Fig. 2. Percentage content (\%) of furosemide in stressed samples after assay. Rectangular bars with figures depict the mean content $(n=5)$ of furosemide in samples subjected to stress conditions (x-axis). Values beyond $100 \pm 5 \%$ indicate occurrence of degradation. ${ }^{*}-\mathrm{P}<0.05$ compared with control sample.

Assay: The initial concentration of furosemide in the samples (day 0) was designated $100 \%$. Concentrations measured on subsequent days were expressed as a percentage of the initial concentration. Stability was defined as the retention of at least $90 \%$ of the original concentration. For example, the concentration of furo- semide in sample $\mathrm{T}_{2}$ on day 30 (fig. 3) as compared to the initial concentration on day 0 was $99.3 \%$. The syrups were considered chemically stable if content $(n=5$, $\mathrm{p}<0.05$ ) of furosemide $\geq 90 \%$ [19]. Fig 3 and Table 2 show us that syrups were within the limit for content of active ingredient in compounded formulations. 
Table 1

Results of stability-indicating thin layer chromatography of furosemide

\begin{tabular}{|c|c|c|c|c|c|c|}
\hline \multirow{2}{*}{ Samples } & \multirow{2}{*}{$\begin{array}{l}\text { Storage Con- } \\
\text { dition }\end{array}$} & \multicolumn{5}{|c|}{$\begin{array}{c}\text { Presence of extra/no spots, position of corresponding spots beyond } \Delta 0.02 \text { of } \\
\text { reference substance over storage period }\end{array}$} \\
\hline & & Day 0 & Day 7 & Day 15 & Day 23 & Day 30 \\
\hline Stressed samples & $78 \pm 2^{\circ} \mathrm{C}$ & \multicolumn{5}{|c|}{+} \\
\hline \multirow{2}{*}{$\mathrm{Fru}_{\mathrm{st}}$} & $5 \pm 3{ }^{\circ} \mathrm{C}$ & - & - & - & - & - \\
\hline & $23 \pm 2{ }^{\circ} \mathrm{C}$ & - & - & - & - & - \\
\hline \multirow{2}{*}{$\mathrm{T}_{1}$} & $5 \pm 3{ }^{\circ} \mathrm{C}$ & - & - & - & - & - \\
\hline & $23 \pm 2{ }^{\circ} \mathrm{C}$ & - & - & - & - & - \\
\hline \multirow{2}{*}{$\mathrm{T}_{2}$} & $5 \pm 3{ }^{\circ} \mathrm{C}$ & - & - & - & - & - \\
\hline & $23 \pm 2{ }^{\circ} \mathrm{C}$ & - & - & - & - & - \\
\hline
\end{tabular}

Note: “-”-absence of extra spots, “+”- presence of extra spots

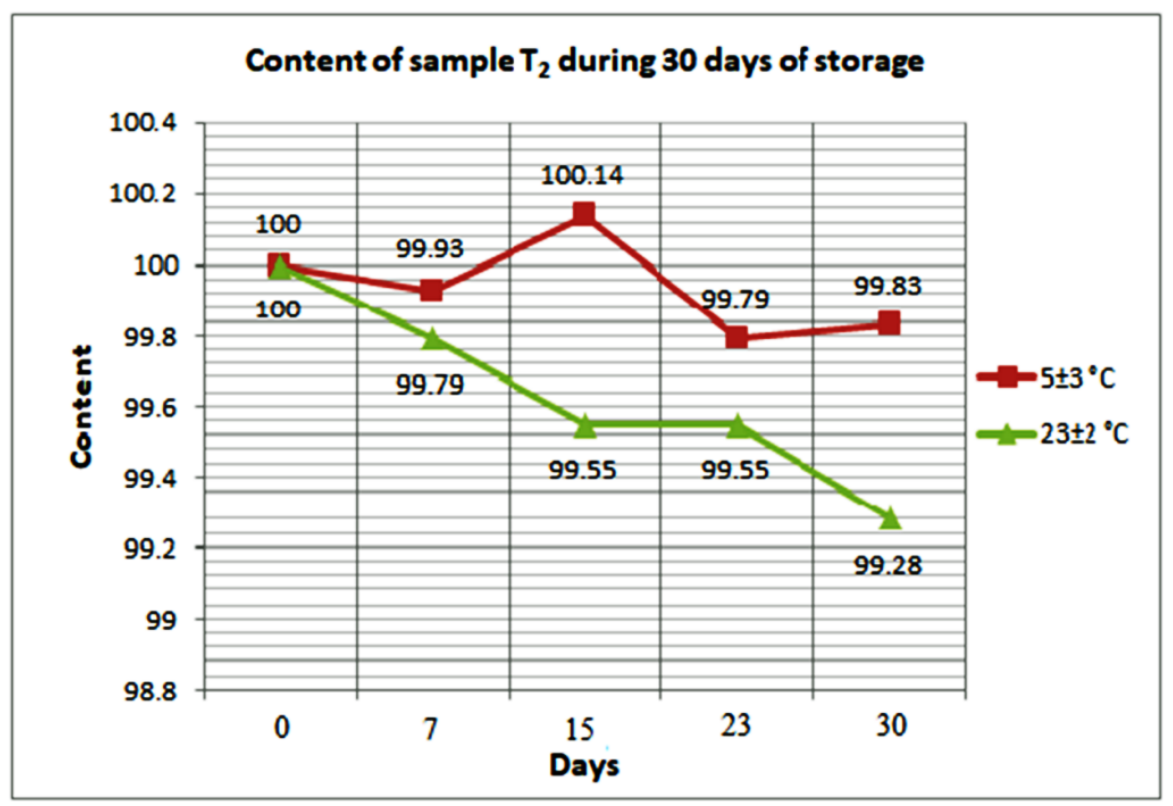

Fig 3. Graphic representation of furosemide content (\%) in sample $\mathrm{T}_{2}$, stored in the dark for a month. ( $\left.\mathrm{n}=5\right)$. Plot shows the assayed values $(\%)$ of furosemide (y-axis) in the syrup made from crushed commercial tablets to understand the rate and degree of loss in its content over a specific period of time (days: $\mathrm{x}$-axis). ${ }^{*}-\mathrm{P}<0.05$ compared with control sample

Content of stored samples over a 30 days period

Table 2

\begin{tabular}{|c|c|c|c|c|c|c|}
\hline \multirow{3}{*}{ Samples } & \multirow{2}{*}{$\begin{array}{c}\text { Storage } \\
\text { Condition }\end{array}$} & \multicolumn{5}{|c|}{ Content $( \pm \mathrm{RSD}$ \%) over storage period, $\mathrm{n}=5$} \\
\cline { 3 - 7 } & & Day 0 & Day 7 & Day 15 & Day 23 & Day 30 \\
\hline \multirow{3}{*}{$\mathrm{Fru}_{\mathrm{st}}$} & $5 \pm 3^{\circ} \mathrm{C}$ & $100.00 \pm 0.25$ & $100.00 \pm 0.14$ & $100.03 \pm 0.12$ & $100.21 \pm 0.12$ & $100.00 \pm 0.14$ \\
\cline { 2 - 7 } & $23 \pm 2{ }^{\circ} \mathrm{C}$ & $100.00 \pm 0.19$ & $100.00 \pm 0.14$ & $100.00 \pm 0.08$ & $100.03 \pm 0.12$ & $99.83 \pm 0.14$ \\
\hline \multirow{2}{*}{$\mathrm{T}_{1}$} & $5 \pm 3^{\circ} \mathrm{C}$ & $100.00 \pm 0.14$ & $100.21 \pm 0.12$ & $100.24 \pm 0.08$ & $100.17 \pm 0.14$ & $100.17 \pm 0.14$ \\
\cline { 2 - 8 } & $23 \pm 2{ }^{\circ} \mathrm{C}$ & $100.00 \pm 0.12$ & $100.14 \pm 0.14$ & $100.17 \pm 0.12$ & $99.96 \pm 0.14$ & $99.76 \pm 0.09$ \\
\hline \multirow{2}{*}{$\mathrm{T}_{2}$} & $5 \pm 3^{\circ} \mathrm{C}$ & $100.00 \pm 0.08$ & $99.93 \pm 0.14$ & $100.14 \pm 0.12$ & $99.79 \pm 0.12$ & $99.83 \pm 0.08$ \\
\cline { 2 - 7 } & $23 \pm 2{ }^{\circ} \mathrm{C}$ & $100.00 \pm 0.14$ & $99.79 \pm 0.12$ & $99.55 \pm 0.09$ & $99.55 \pm 0.15$ & $98.28 \pm 0.27$ \\
\hline
\end{tabular}

Physical stability. The physical instability was defined as a change in colour, taste, appearance or formation of gas in the stored preparation. During the 30 days period of study, there was no significant change (Table 3) in physical appearance, odour, colour or taste for the preparations stored in the dark at both $5 \pm 3{ }^{\circ} \mathrm{C}$ and $23 \pm 2{ }^{\circ} \mathrm{C}$. 
Physical stability of compounded furosemide syrups

\begin{tabular}{|c|c|c|c|c|c|c|c|}
\hline $\begin{array}{c}\text { Sample }(5 \mathrm{mg} / \mathrm{ml}) \\
\text { Storage temperature }\end{array}$ & Day & $\begin{array}{c}\mathrm{pH}( \pm \mathrm{RSD}) \\
\mathrm{n}=5\end{array}$ & $\begin{array}{l}\text { Change in } \\
\text { taste }\end{array}$ & Gas & Odour & Colour & $\begin{array}{c}\text { Viscosity }\left(\mathrm{mm}^{2} / \mathrm{s}\right), \\
\mathrm{n}=5\end{array}$ \\
\hline \multicolumn{8}{|c|}{ Syrup from furosemide substance, Fru $_{\text {st, }}$} \\
\hline \multirow{5}{*}{$5 \pm 3^{\circ} \mathrm{C}$} & 0 & $4.94 \pm 0.23$ & - & - & - & - & $124.35 \pm 0.69$ \\
\hline & 7 & $4.93 \pm 0.23$ & - & - & - & - & $124.73 \pm 0.30$ \\
\hline & 15 & $4.94 \pm 0.17$ & - & - & - & - & $125.36 \pm 0.23$ \\
\hline & 23 & $4.95 \pm 0.14$ & - & - & - & - & $125.97 \pm 0.28$ \\
\hline & 30 & $4.95 \pm 0.23$ & - & - & - & - & $124.89 \pm 0.34$ \\
\hline \multirow{5}{*}{$23 \pm 2{ }^{\circ} \mathrm{C}$} & 0 & $4.94 \pm 0.11$ & - & - & - & - & $124.37 \pm 0.36$ \\
\hline & 7 & $4.94 \pm 0.23$ & - & - & - & - & $124.30 \pm 0.58$ \\
\hline & 15 & $4.93 \pm 0.17$ & - & - & - & - & $124.01 \pm 0.18$ \\
\hline & 23 & $4.94 \pm 0.23$ & - & - & - & - & $124.32 \pm 0.21$ \\
\hline & 30 & $4.93 \pm 0.09$ & - & - & - & - & $124.25 \pm 0.36$ \\
\hline \multicolumn{8}{|c|}{ Syrup from furosemide tablets, $T_{1}$} \\
\hline \multirow{5}{*}{$5 \pm 3{ }^{\circ} \mathrm{C}$} & 0 & $5.25 \pm 0.18$ & - & - & - & - & $134.04 \pm 1.19$ \\
\hline & 7 & $5.27 \pm 0.30$ & - & - & - & - & $134.28 \pm 1.44$ \\
\hline & 15 & $5.28 \pm 0.22$ & - & - & - & - & $135.39 \pm 0.76$ \\
\hline & 23 & $5.27 \pm 0.13$ & - & - & - & - & $135.72 \pm 0.57$ \\
\hline & 30 & $5.28 \pm 0.24$ & - & - & - & - & $135.47 \pm 0.29$ \\
\hline \multirow{5}{*}{$23 \pm 2{ }^{\circ} \mathrm{C}$} & 0 & $5.25 \pm 0.18$ & - & - & - & - & $134.93 \pm 0.57$ \\
\hline & 7 & $5.24 \pm 0.32$ & - & - & - & - & $133.77 \pm 0.91$ \\
\hline & 15 & $5.23 \pm 0.40$ & - & - & - & - & $135.20 \pm 0.59$ \\
\hline & 23 & $5.23 \pm 0.25$ & - & - & - & - & $135.02 \pm 0.85$ \\
\hline & 30 & $5.23 \pm 0.25$ & - & - & - & - & $135.00 \pm 0.53$ \\
\hline \multicolumn{8}{|c|}{ Syrup from furosemide tablets, $\mathrm{T}_{2}$} \\
\hline \multirow{5}{*}{$5 \pm 3{ }^{\circ} \mathrm{C}$} & 0 & $5.18 \pm 0.32$ & - & - & - & - & $130.14 \pm 0.32$ \\
\hline & 7 & $5.17 \pm 0.29$ & - & - & - & - & $130.61 \pm 0.08$ \\
\hline & 15 & $5.18 \pm 0.16$ & - & - & - & - & $131.63 \pm 0.13$ \\
\hline & 23 & $5.18 \pm 0.44$ & - & - & - & - & $131.79 \pm 0.15$ \\
\hline & 30 & $5.19 \pm 0.25$ & - & - & - & - & $131.93 \pm 0.10$ \\
\hline \multirow{5}{*}{$23 \pm 2{ }^{\circ} \mathrm{C}$} & 0 & $5.18 \pm 0.09$ & - & - & - & - & $130.11 \pm 0.21$ \\
\hline & 7 & $5.18 \pm 0.14$ & - & - & - & - & $130.28 \pm 0.36$ \\
\hline & 15 & $5.16 \pm 0.26$ & - & - & - & - & $130.35 \pm 0.27$ \\
\hline & 23 & $5.15 \pm 0.11$ & - & - & - & - & $130.94 \pm 0.12$ \\
\hline & 30 & $5.15 \pm 0.16$ & - & - & - & - & $130.43 \pm 0.13$ \\
\hline
\end{tabular}

\section{Key: “-”-absence of change}

No visible culture growths were observed. Values of $\mathrm{pH}$ were within \pm 0.05 . Values for viscosity at a particular storage temperature range didn't differ by $1 \%$.

The difference in viscosity for $\mathrm{T}_{1}$ and $\mathrm{T}_{2}$ samples is caused by the difference in the excipient composition of manufactured furosemide tablets.

Microbiological stability. Microbial contamination on different stages of compounding may affect the microbial purity of extemporal preparations. In order to confirm that the microbiological stability of the proposed syrup exceeds the USP's recommended storage period, cultures of the samples were taken on above-mentioned designated days (Table 4) and assessed. The samples were prepared in non-standard compounding cabinets to mimic less optimum conditions that may be found in resource-limited countries. All samples, met the criteria for microbiological quality of non-sterile pharmaceutical preparations and substances for pharmaceutical use microbiological safety of non-sterile oral preparations, based upon the total aerobic microbial count (TAMC $<100)$ and the total combined yeasts/moulds count (TYMC <10). Throughout the duration of study, no presence of Escherichia coli, in the studied samples, was observed. 
Results from microbiological examination

\begin{tabular}{|c|c|c|c|c|c|c|c|c|c|c|c|c|c|c|c|c|}
\hline \multirow{4}{*}{ Samples } & \multirow{4}{*}{$\begin{array}{c}\text { Condition of } \\
\text { storage }\end{array}$} & \multicolumn{15}{|c|}{ Two-layer plating method } \\
\hline & & \multicolumn{15}{|c|}{ Quantity in $1 \mathrm{~g}$} \\
\hline & & \multicolumn{5}{|c|}{$\begin{array}{l}\text { Total aerobic microbial } \\
\text { count(TAMC } \leq 100)\end{array}$} & \multicolumn{5}{|c|}{$\begin{array}{l}\text { Total combined mould/yeast } \\
\text { count(TYMC } \leq 10)\end{array}$} & \multicolumn{5}{|c|}{$\begin{array}{l}\text { Escherichia coli } \\
\text { (absence in } 1 \mathrm{~g} \text { ) }\end{array}$} \\
\hline & & $\begin{array}{c}\text { Day } \\
0\end{array}$ & $\begin{array}{c}\text { Day } \\
7 \\
\end{array}$ & $\begin{array}{c}\text { Day } \\
14\end{array}$ & $\begin{array}{c}\text { Day } \\
21\end{array}$ & $\begin{array}{c}\text { Day } \\
30\end{array}$ & $\begin{array}{c}\text { Day } \\
0\end{array}$ & $\begin{array}{c}\text { Day } \\
7\end{array}$ & $\begin{array}{c}\text { Day } \\
14\end{array}$ & $\begin{array}{c}\text { Day } \\
21\end{array}$ & $\begin{array}{c}\text { Day } \\
30\end{array}$ & $\begin{array}{c}\text { Day } \\
0\end{array}$ & $\begin{array}{c}\text { Day } \\
7\end{array}$ & $\begin{array}{c}\text { Day } \\
14 \\
\end{array}$ & $\begin{array}{c}\text { Day } \\
21\end{array}$ & $\begin{array}{c}\text { Day } \\
30\end{array}$ \\
\hline \multirow{2}{*}{$\mathrm{Fru}_{\mathrm{st}}$} & $\mathrm{t}=5 \pm 3{ }^{\circ} \mathrm{C}$ & 20 & 20 & 21 & 23 & 24 & $<10$ & $<10$ & $<10$ & $<10$ & $<10$ & & & & & \\
\hline & $\mathrm{t}=23 \pm 2{ }^{\circ} \mathrm{C}$ & 10 & 11 & 16 & 23 & 29 & $<10$ & $<10$ & $<10$ & $<10$ & $<10$ & & & & & \\
\hline \multirow{2}{*}{$\mathrm{T}_{1}$} & $\mathrm{t}=5 \pm 3{ }^{\circ} \mathrm{C}$ & 20 & 21 & 23 & 25 & 27 & $<10$ & $<10$ & $<10$ & $<10$ & $<10$ & & & & & \\
\hline & $\mathrm{t}=23 \pm 2{ }^{\circ} \mathrm{C}$ & 300 & 309 & 314 & 320 & 327 & $<10$ & $<10$ & $<10$ & $<10$ & $<10$ & & & & & \\
\hline \multirow{2}{*}{$\mathrm{T}_{2}$} & $\mathrm{t}=5 \pm 3{ }^{\circ} \mathrm{C}$ & 20 & 21 & 21 & 23 & 25 & $<10$ & $<10$ & $<10$ & $<10$ & $<10$ & & $=$ & & & \\
\hline & $\mathrm{t}=23 \pm 2{ }^{\circ} \mathrm{C}$ & 25 & 26 & 27 & 30 & 32 & $<10$ & $<10$ & $<10$ & $<10$ & $<10$ & & & & & \\
\hline
\end{tabular}

Key: “-"-absence of investigated organism

Sedimentation volume. Samples stored at $5 \pm 3$ and $23 \pm 2{ }^{\circ} \mathrm{C}$ had sedimentation volumes $\geq 0.94\left(\mathrm{~T}_{1}-\right.$ 0.947, $\left.\mathrm{T}_{2}-0.940\right)$. High sedimentation volumes of our syrup suspensions are partly due to the nature of our dispersion medium.
The results for content uniformity (Tables 5, 6) showed that values $\left(\mathrm{T}_{1}-10.56 \%, \mathrm{~T}_{2}-5.76 \%\right)$ were within the limits of the pharmacopoeia $(\leq 15.0 \%)$. Samples of the syrup met the acceptance criteria for content uniformity.

Table 5

Uniformity of dosage units $\left(\mathrm{T}_{1}\right)$

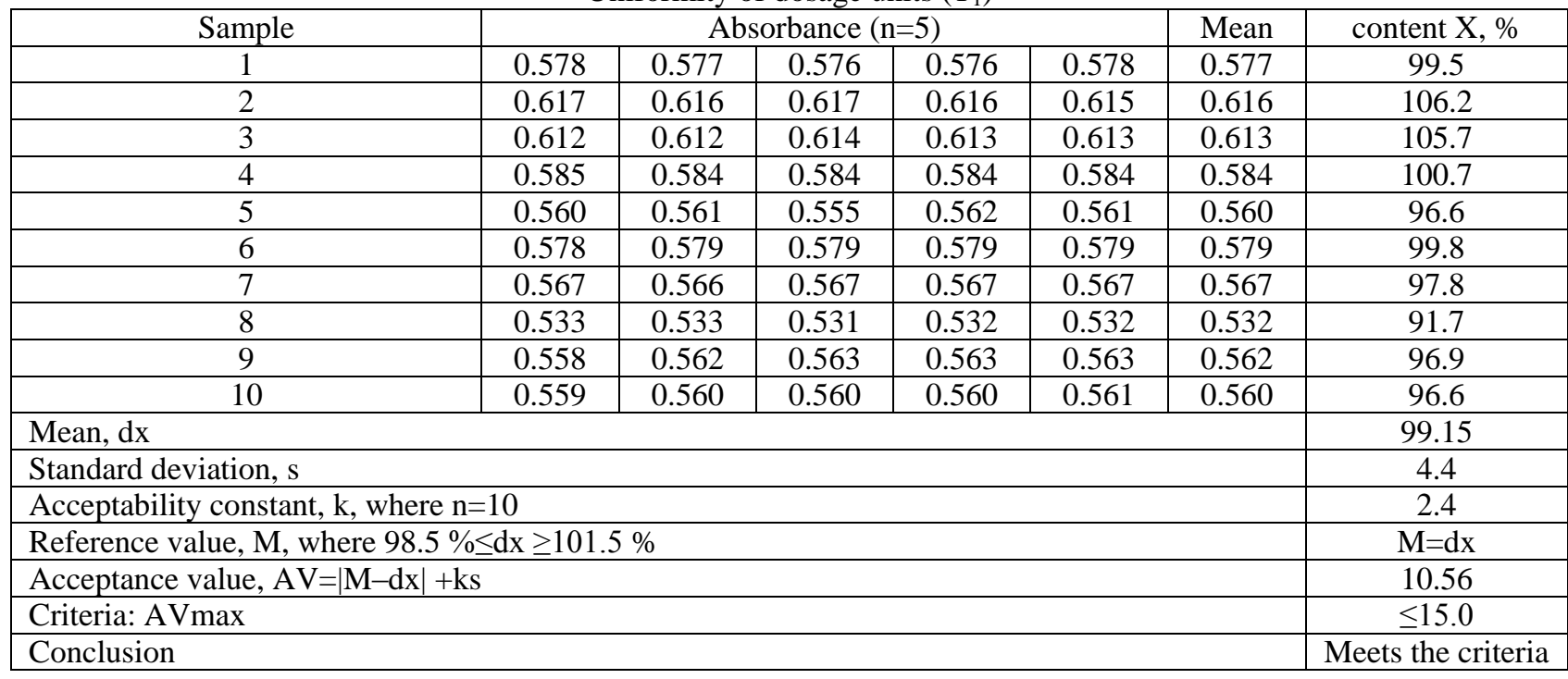

Uniformity of dosage units $\left(\mathrm{T}_{2}\right)$

\begin{tabular}{|c|c|c|c|c|c|c|c|}
\hline Sample & \multicolumn{5}{|c|}{ Absorbance $(n=5)$} & Mean & content $\mathrm{X}, \%$ \\
\hline 1 & 0.582 & 0.582 & 0.583 & 0.581 & 0.58 & 0.582 & 100.3 \\
\hline 2 & 0.587 & 0.586 & 0.586 & 0.586 & 0.587 & 0.586 & 101.1 \\
\hline 3 & 0.577 & 0.578 & 0.578 & 0.579 & 0.576 & 0.578 & 99.6 \\
\hline 4 & 0.574 & 0.573 & 0.572 & 0.573 & 0.573 & 0.573 & 98.8 \\
\hline 5 & 0.554 & 0.555 & 0.555 & 0.553 & 0.552 & 0.554 & 95.5 \\
\hline 6 & 0.607 & 0.607 & 0.605 & 0.604 & 0.605 & 0.606 & 104.4 \\
\hline 7 & 0.576 & 0.574 & 0.575 & 0.575 & 0.576 & 0.575 & 99.2 \\
\hline 8 & 0.585 & 0.586 & 0.586 & 0.586 & 0.585 & 0.586 & 101.0 \\
\hline 9 & 0.566 & 0.565 & 0.565 & 0.567 & 0.565 & 0.566 & 97.5 \\
\hline 10 & 0.569 & 0.572 & 0.573 & 0.572 & 0.57 & 0.571 & 98.5 \\
\hline \multicolumn{7}{|l|}{ Mean, dx } & 99.58 \\
\hline \multicolumn{7}{|c|}{ Standard deviation, $\mathrm{s}$} & 2.4 \\
\hline \multicolumn{7}{|c|}{ Acceptability constant, $\mathrm{k}$, where $\mathrm{n}=10$} & 2.4 \\
\hline \multicolumn{7}{|c|}{ Reference value, $\mathrm{M}$, where $98.5 \% \leq \mathrm{dx} \geq 101.5 \%$} & $\mathrm{M}=\mathrm{dx}$ \\
\hline \multicolumn{7}{|c|}{ Acceptance value, $\mathrm{AV}=|\mathrm{M}-\mathrm{dx}|+\mathrm{ks}$} & 5.76 \\
\hline \multicolumn{7}{|c|}{ Criteria: AVmax } & $\leq 15.0$ \\
\hline \multicolumn{7}{|l|}{ Conclusion } & Meets the criteria \\
\hline
\end{tabular}




\section{Conclusion}

Extemporal syrups of furosemide substance and dispersed furosemide tablets in syrup USP, stored in glass bottles in the dark at $5 \pm 3{ }^{\circ} \mathrm{C}$ and $23 \pm 2{ }^{\circ} \mathrm{C}$, were found to be physically, chemically and microbiologically stable for at least 30 days.

\section{Recommendation}

Due to differences in each manufacturer's composition of ready products (tablets, capsules etc), we sug- gest a more conservative beyond-use-date for extemporaneous furosemide syrups.

Financial support: Nil.

Conflict of interest: None to declare.

Acknowledgements: We thank prof. Strilets O. P. from the Department of Biotechnology, National University of Pharmacy, Kharkiv, Ukraine for assistance with investigations of microbiological purity of compounding syrups.

\section{References}

1. Giam, J. A. Extemporaneous product use in paediatric patients: a systematic review [Text] / J. A. Giam, A. J. McLachlan // International Journal of Pharmacy Practice. - 2008. - Vol. 16, Issue 1. - P. 3-10. doi: 10.1211/ijpp.16.1.0002

2. Allen, L. V. The Art, Science, and Technology of Pharmaceutical Compounding [Text] / L. V. Allen. - Washington D.C.: American Pharmacists Association, 2016. doi: 10.21019/9781582122632

3. Diorio, L. Evaluating stability data understanding beyond-use dating for compounded sterile preparations [Text] / L. Diorio, D. Thomas // Pharmacy, purchasing \& products. - 2009. - Vol. 4. - P. 12-14.

4. Pharmaceutical Compounding. The United States Pharmacopeia [Text]. - 39th ed. - Rockville: The United States Pharmacopeial Convention, 2016.

5. Mason, B. Capstone pharmacy review [Text] / B. B. Mason, D. Parker, R. Lott. - Burlington: Jones \& Bartlett Learning, 2013. - P. 107-108.

6. Pharmaceutical Compounding - Nonsterile Preparations <795> [Electronic resource]. - Available at: http://www.usp.org/compounding/general-chapter-795

7. Stoehr, N. Compound Academy Solutions and Suspensions [Text] / N. Stoehr // American College of Apothecaries. - 2017. P. 22-71. - Available at http://acainfo.org/wp-content/uploads/2017/07/L5-Compound-Academy-Solutions-and-Suspensions.pdf

8. McNulty, J. P. Compounded Drugs of Value in Outpatient Hospice and Palliative Care Practice [Text] / J. P. McNulty, G. Muller // Int J Pharm Compd. - 2014. - Vol. 18, Issue 30. - P. 190-200.

9. Allen, L. V. Stability of Extemporaneously Prepared Oral Liquid Formulations - Part VIII [Text] / L. V. Allen // Secundum Artem. - 2011. - Vol. 16, Issue 3. - P. 1-6.

10. Salgado, A. C. Stability of spironolactone in an extemporaneously prepared aqueous suspension: the importance of microbiological quality of compounded paediatric formulations [Text] / A. C. Salgado, L. Rosa, A. Duarte, A. J. Almeida // The European Journal of Hospital Pharmacy Science. - 2005. - Vol. 11, Issue 3. - P. 68-73.

11. Niazi, K. Handbook of Pharmaceutical Manufacturing Formulations: Liquid Products [Text] / K. Niazi. - New York: Informa Healthcare, 2009. doi: 10.3109/9781420081244

12. Alfred-Ugbenbo, D. Compounding in Nigeria [Text] / D. Alfred-Ugbenbo, O. A. Zdoryk, V. A. Georgiyants, R. Schnatz // International Journal of Pharmaceutical Compounding. - 2016. - Vol. 20, Issue 3. - P. 189-192.

13. Allen, L. V. A formulation for preparing Syrup NF [Text] / L. V. Allen // International Journal of Pharmaceutical Compounding. - 1997. - Vol. 2, Issue 1. - P. 111.

14. State Pharmacopoeia of Ukraine [Text]. - 2nd ed. - Kharkiv: State Enterprise «Ukrainian Scientific Pharmacopoeial Center for Quality of Medicines», 2014.

15. Alfred-Ugbenbo, D. Validation of analytical method for determination of furosemide in extemporaneous syrup [Text] / D. Alfred-Ugbenbo, O. A. Zdoryk, V. A. Georgiyants // Medical and Clinical Chemistry. - 2017. - Vol. 19, Issue 2. - P. 5-11. doi: 10.11603/mcch.2410-681x.2017.v0.i2.7859

16. European pharmacopoeia [Text]. - 7th ed. - Strasbourg: Council of Europe, 2011.

17. Florence, A. Modern Pharmaceutics [Text] / A. Florence, J. Siepmann. - CRC Press, 2009. - 1216 p. doi: 10.1201/ b14445

18. Aremu, O. I. Evaluation of metronidazole suspensions [Text] / O. I. Aremu, O. O. Oduyela // African Journal of Pharmacy and Pharmacology. - 2015. - Vol. 9, Issue 12. - P. 439-450. doi: 10.5897/ajpp2014.4036

19. Lam, M. S. H. Extemporaneous Compounding of Oral Liquid Dosage Formulations and Alternative Drug Delivery Methods for Anticancer Drugs [Text] / M. S. H. Lam // Pharmacotherapy. - 2011. - Vol. 31, Issue 2. - P. 164-192. doi: 10.1592/ phco.31.2.164

Дата надходження рукопису 23.08.2017

Deghinmotei Alfred-Ugbenbo, Postgraduate student, National University of Pharmacy, Pushkinska str., 53, Kharkiv, Ukraine, 61002

E-mail: audeghinmotei@gmail.com

Zdoryk Oleksandr, PhD, Associate professor, Department of Pharmaceutical chemistry, National University of Pharmacy, Pushkinska str., 53, Kharkiv, Ukraine, 61002

E-mail: oleksandr_zdoryk@ukr.net

Georgiyants Viktoria, Doctor of pharmaceutical sciences, Professor, Head of department, Department of Pharmaceutical chemistry, National University of Pharmacy, Pushkinska str., 53, Kharkiv, Ukraine, 61002 E-mail: vgeorg@ukr.net 